\title{
Classification and categorization of Brazilian agricultural startups (Agtechs)
}

\author{
Paulo Henrique Bertucci Ramos and Marcelo Caldeira Pedroso \\ Department of Administration, Faculty of Economics, \\ Administration and Accounting, University of São Paulo, São Paulo, Brazil
}

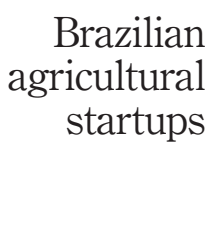

237

Received 31 December 2019 Revised 1 May 2020 Accepted 26 July 2020

\begin{abstract}
Purpose - This paper aims to identify and analyze the agtech classification and categorization systems in the Brazilian context.

Design/methodology/approach - The systematic literature review (SLR) was carried out according to the protocol of Kitchenham and Charters (2007). The classification systems found in literature were evaluated using the thinking aloud protocol, as proposed by Ericsson and Simon (1993). The responses obtained were evaluated through lexicographic analysis, described by Bécue-Bertaut (2019) and content analysis, described by Bardin (2011). Findings - SLR identified four agtech classification systems. The model proposed by Dias, Jardim, and Sakuda (2019) was the one with the highest adherence to classify Brazilian agtechs. From the analysis of the systems found in literature, the authors proposed a new categorization model of agricultural startups (agtechs).

Research limitations/implications - The study has limitations in relation to the theoretical and empirical validation of the model proposed by the authors. This limitation can be the subject of subsequent research.

Practical implications - The SLR study considers the evolution of the classification systems of a new agribusiness reality, the agtechs. In addition, there is a practical contribution in proposing a new classification system that attempts to address some of the limitations found in previous studies.

Originality/value - Agtechs are startups focused on developing solutions for agriculture and have shown a significant increase in recent years. However, there are few studies focused on this type of company. Even rarer are the studies that seek to classify and categorize them. The present work opens the horizon for future studies focused on this new reality.
\end{abstract}

Keywords Entrepreneurship, Agribusiness, Innovation, Startups, Agtechs

Paper type Research paper

\section{Introduction}

The agricultural sector, represented by agribusiness, is one of the main sectors supporting the Brazilian economy. While other sectors of the economy tend to experience greater impacts in times of economic recession, agribusiness is generally less impacted. Between 2000 and 2018, the Gross Domestic Product generated by agribusiness [GDP-Agribusiness]

(C) Paulo Henrique Bertucci Ramos and Marcelo Caldeira Pedroso. Published in Innovation and Management Review. Published by Emerald Publishing Limited. This article is published under the Creative Commons Attribution (CC BY 4.0) licence. Anyone may reproduce, distribute, translate and create derivative works of this article (for both commercial and non-commercial purposes), subject to full attribution to the original publication and authors. The full terms of this licence may be seen at http://creativecommons.org/licences/by/4.0/legalcode

This study was financed in part by the Coordenação de Aperfeiçoamento de Pessoal de Nível Superior - Brasil (CAPES) - Finance Code 001. The authors would like to thank Prof. Dr Erick Saldaña for his help with the lexicographic analysis.

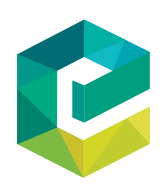

Innovation \& Management Review Vol. 18 No. 3,2021 pp. $237-257$ Emerald Publishing Limited $2515-896$ 
INMR 18,3

grew 320\%, reaching 1.6 trillion reais (Center for Advanced Studies on Applied Economics [CEPEA], 2018), while Brazilian GDP in 2018 was 6.8 trillion reais (Brazilian Institute of Geography and Statistics [IBGE], 2018). According to Barros (2017), between 2014 and 2017, the GDP of the industrial transformation and services sectors decreased by around 12.1 and $5 \%$, respectively, in contrast to the agricultural sector, which had an increase of $11.7 \%$.

It is undeniable that much of GDP-Agribusiness is the result of large-scale production from large agricultural companies. However, the participation of small and medium-sized agricultural companies in GDP-Agribusiness increases every decade. According to Guilhoto, Silveira, Ichihara, and Azzoni (2006), about 10\% of the GDP-Agribusiness comes from small and medium rural companies. When considering medium and small companies, from 2014 onwards, they represent $27 \%$ of all GDP (Costa \& Leandro, 2016).

The adoption of new technologies, mainly tools from Agriculture - 4.0, also called Digital Agriculture, such as drones, sensors, machine to machine communication (M2M) linked to the internet of things (IoT), agricultural data processing and creation of applications for management decision-making, was decisive for Brazilian agriculture to achieve high levels of production and profitability (Massruhá \& Leite, 2016).

The offering of innovative (or disruptive) products and services in agribusiness is, in part, carried out primarily by startups. According to Blank and Dorf (2012), startup is a temporary organization in search of a scalable, recurring and profitable business model. In addition, a startup can be understood as a human institution designed to create products and services in situations of uncertainty (Ries, 2012).

According to Dutia (2014) and Manne and Stout (2017), startups focused on agriculture, called agtechs, are companies oriented toward technological advances in chemical, biological, administrative and mechanical processes. These advances bring greater income to agricultural crops, in addition to reducing production costs and the complexity of agricultural activity.

In recent years, billions of dollars have been invested in activities covered by agtechs. Studies indicate that this global amount ranges from US\$3bn (Graff, Silva, \& Zilberman, 2019) to US\$6.8bn annually (AgFunder, 2019).

Although the diversity of services offered by agtechs is a differential to encourage investment and enable satisfactory gains for entrepreneurs, it hinders the classification and ordering of the business model of these startups.

According to the presented, the objective of this article is to carry out a systematic literature review (SLR) to identify and analyze the systems of classification and categorization of agtechs in the Brazilian context. This SLR sought to answer the research question: "How to classify and categorize Brazilian agtechs?" In addition, it aimed to propose a new classification system that considers the possible gaps in current systems.

\section{Literature review}

Startup is a term used to designate companies newly established in the market and that are in the process of validating their business model. They are generally characterized as innovative and disruptive, in addition to presenting high risks in the product concept and relatively low operating cost (Ries, 2012).

A startup differs from a traditional company because the latter seeks growth and profitability, while the startup aims to verify whether its business model can develop into a sustainable and profitable business. When the uncertainty regarding the validity of the business model disappears, the startup moves to a new stage, since the company's objective becomes growth and profitability, like any conventional company (Blank \& Dorf, 2012). 
Startups play an important role in the development of local economies. Studies show their impact on the amount of wealth generated by countries. According to Malik (2013), between 2007 and 2011, London's economy grew about 12.5\% more than the rest of the country with the installation of a startup incubator. Schneck and May-Strobl (2015) demonstrated that $6.5 \%$ of sales in Germany originate from nascent companies. Sabella, Farraj, Burbar, and Qaimary (2014) state that the adoption of a policy of greater incentive to entrepreneurship and, consequently, of incentives to startups, increased the Gross Domestic Product (GDP) of Palestine by $7.33 \%$ when compared to previous years. According to the Brazilian Association of Startups [ABStartups] (2017), in Brazil startups grew 18\% compared to 2014 and 2015, resulting in an investment of 2 billion reais in the economy and a participation of $0.33 \%$ of the total Brazilian GDP, with an expectation that this value will reach $5 \%$ of GDP $(\mathrm{R} \$ 276$ billion) by 2035 .

Graff et al. (2019) reported that, from a sample of 4,552 agtechs with great prominence in the international market, those located in emerging countries correspond to $13 \%$ of the total, with 210 agtechs established in India, 172 in China, 88 in Brazil, 58 in Russia and 41 in South Africa.

According to the global network of independent consultants created by Klynveld, Peat, Marwick \& Goerdeler [KPMG] (KPMG, 2018), companies dedicated to agribusiness correspond to $3.3 \%$ of all active Brazilian companies, with agtechs playing an important role for representing around $10 \%$ of the GDP-Agribusiness. Considering the annual gross revenue, $46.5 \%$ of the agtechs have a forecast revenue between 60 and 360 thousand reais, $18.2 \%$ between 1.5 and 5 million reais and $15.6 \%$ between 360 thousand and 1.5 million reais.

The ways in which Brazilian agtechs achieve this gross revenue are diverse and reflect how agriculture 4.0 is being developed in Brazil. According to Ozdogan, Gacar, and Aktas (2017), agriculture 4.0 means the use of technologies, both from information technology and communication, to increase profitability and sustainability in agriculture. With the adoption of agriculture 4.0, the producer can use several tools to optimize systems, have high precision in the adoption of the activity and customize information (Es et al., 2016; Deichmann, Goyal, \& Mishra, 2016).

Massruhá and Leite (2016) state that the use of agriculture 4.0, together with agtechs, modified Brazilian agriculture. This modification occurred through the insertion of computerized methods, sensors, machine to machine communication (M2M), connectivity between mobile devices, cloud computing, methods and analytical solutions for processing large volumes of information and building support systems for decision-making. The Internet of Things (IoT) allows everyday objects, whatever they may be, to be connected to the internet" (Santos et al., 2016, p. 1). Cloud computing is considered "any type of service accessed via the internet or IP network that can be expanded or reduced in a short period of time, according to demand and whose charge - if any - is based on use" (Torres \& Alves, 2017, p. 4). Drone is defined as "a vehicle or device that moves in a specific environment, usually in the air, through a remote control and often equipped with a device for recording or transmitting images" (Casteleiro, 2001). Artificial intelligence (AI) is an area of computer science that seeks to reproduce, by computational means, the ability to reason, plan, solve problems, perform induction, logical deduction and abduction, in addition to storing knowledge (Bellman, 1978).

According to Graff et al. (2019), the provision of technological services in agriculture 4.0 is the specialty most offered by agtechs created globally. According to these authors, about $54 \%$ of agtechs with international prominence are providers of technological services for agriculture. 
INMR

18,3

\section{0}

\section{Research method}

The research method of this work considered three stages:

(1) systematic literature review (SLR), carried out according to the protocol of Kitchenham and Charters (2007);

(2) field research, which used three techniques: thinking aloud, as proposed by Ericsson and Simon (1993); lexicographic analysis, described by Bécue-Bertaut (2019); and content analysis, described by Bardin (2011); and

(3) proposition of a categorization model.

\subsection{Systematic literature review}

Different references (i.e. articles published in scientific journals and academic congress, white papers and books) were examined to identify patterns and relationships about the agtechs construct. The SLR technique was used to discover the main types of agtechs classification cited by previous studies. The grouping of the mentioned categories and the development of a descriptive analysis of the construct was performed through conceptual affinity segmentation. According to Crossan and Apaydin (2010) and Pittaway and Cope (2007), the use of literature with a systematic approach provides a favorable context for a better understanding of the ideas and theories on the subject. Additionally, the SLR allows theoretical and empirical investigation, to build the relationship of the current state of the art, with a focus on future research.

The systematic literature review was conducted according to the method proposed by Kitchenham and Charters (2007), which consists of seven steps:

(1) selection of the research question that will guide the study;

(2) selection of terms and digital libraries;

(3) identification of the inclusion and exclusion criteria of the studies;

(4) identification of the quality assessment procedures of the selected studies;

(5) data extraction and synthesis;

(6) quantitative or qualitative analysis of the results; and

(7) presentation of the summary of the documentation and availability.

The research question for conducting the SLR was: how to classify and categorize Brazilian agtechs?

Desk research addressed the following scientific bases: Web of Science, Scopus, Portal Capes and Springer. Google Scholar was considered as a supplementary database. The research was carried out in July 2019, covering the search period for articles published until 2019. Keywords used were <startups>, <agtechs>, <agriculture 4.0>, <agricultural technology $>$, <agricultural innovation and classification>, besides their respective translations in Portuguese. The term "classification" was applied to all filters and the other terms were used in a combinatory approach, totaling 15 set of terms:

(1) classification + startup;

(2) classification + agtechs;

(3) classification + agriculture 4.0;

(4) classification + agricultural technology;

(5) classification + agricultural innovation; 
(6) classification + startup + agtechs;

(7) classification + startup + agriculture 4.0;

(8) classification + startup + agricultural technology;

(9) classification + startup + agricultural innovation;

(10) classification + agtechs + agriculture 4.0;

(11) classification + agtechs + agricultural technology;

(12) classification + agtechs + agricultural innovation;

(13) classification + agriculture 4.0 + agricultural technology;

(14) classification + agriculture $4.0+$ agricultural innovation; and

(15) classification + agricultural technology + agricultural innovation.

Exclusion criteria adopted in this SLR were cross-references in the databases and adherence to the study area.

\subsection{Field research}

The classification and categorization models obtained in the SLR were analyzed considering their positive and negative aspects. This analysis was performed with the aid of the thinking aloud verbal protocol, proposed by Ericsson and Simon (1993). Five thinking aloud sessions were held with researchers in the field of agribusiness. The researchers work at the Federal University of São Carlos, Campus Lagoa do Sino. These researchers were selected for having knowledge in the area, as they carry out research in the administration course focused on agribusiness systems.

In each session, participants listened to an audio with a brief introduction about the agtechs and their classifications, the rules of the session and a reminder for the participant to speak throughout the process. After the audio, the participants received four sheets of A4 paper with the different types of classification found in the SLR. The participants also received another sheet of A4 paper with a task to be performed by the participants: to present the positive and negative aspects of each model.

The recordings were listened, transcribed and interpreted in search of similarity patterns

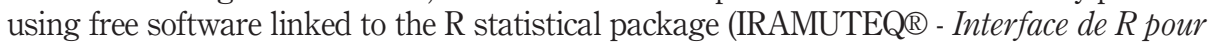
les Analyses Multidimensionnelles de Textes et de Questionnaires). Analysis platforms followed the guidelines developed by Bécue-Bertaut (2019) for lexicographic analysis and Bardin (2011) for content analysis.

Lexicographic analysis consisted of two steps: the first considered the preprocessing of thinking aloud sessions. In this stage, aspects related to the ironies and jokes of the participants' speeches were eliminated. This step is important, as this type of analysis considers literal aspects of the discourse. The second step was the lexicographic analysis, which initially included the elaboration of a lexical table containing the positive and negative aspects of each classification, according to each participant in the thinking aloud session. After the creation of this table, a correspondence analysis of the lexicons was performed, adopting the singular value of each speech decomposition (Greenacre, 2010). From this decomposition, frequency graphs were created to represent the dimensions of the statements obtained.

For content analysis, the transcribed material was segmented into units of analysis. These units contained segments of the interviews, considering the negative and positive aspects of each classification system. The units were then subjected to inferences and interpretations, supported by the theoretical framework studied. 
INMR

18,3

\subsection{Proposition of a new categorization model}

Based on the analysis of the classification and categorization models identified in the literature and the results of the field research, the authors proposed a new categorization model for agricultural startups (agtechs). For the construction of this new model, both the positive and negative segments of the lexicographic and content analysis of the classification models obtained in the SLR were considered. These analyses, in turn, were originated from notes obtained in the sessions of the thinking aloud verbal protocol.

\section{Results of the systematic literature review}

Figure 1 shows the steps and respective filters used in the SLR.

From this SLR, 610 entries were initially obtained, whose study spectra were related to the filters used. Although the chosen databases were appropriate for conducting the desk research, it allows the same entry to be indexed in more than one database. Therefore, an exclusion criterion was used, eliminating 326 duplicate entries. The resulting 284 articles were analyzed by reading the abstract and, within this step, 254 entries were eliminated. These exclusions were performed because, although the entries met the filters, they did not present a model of agtech classification. The remaining 30 entries were analyzed by reading their full content and checked whether their existing agtech classifications were addressed effectively or even tangentially. According to this criterion, only four entries presented a complete and structured model of agtech classification that could be used in the Brazilian context. Table 1 shows the analyzed articles.

The first classification model cited was proposed by Graff et al. (2019), which considers the types and service offerings that each agtech can deliver for specific categories. The categories presented were Business \& financial services; Online services and content; Biotech, genetics and heath; Chemicals; Software, data and information technology (IT);

Figure 1.

Steps and filters used in SLR

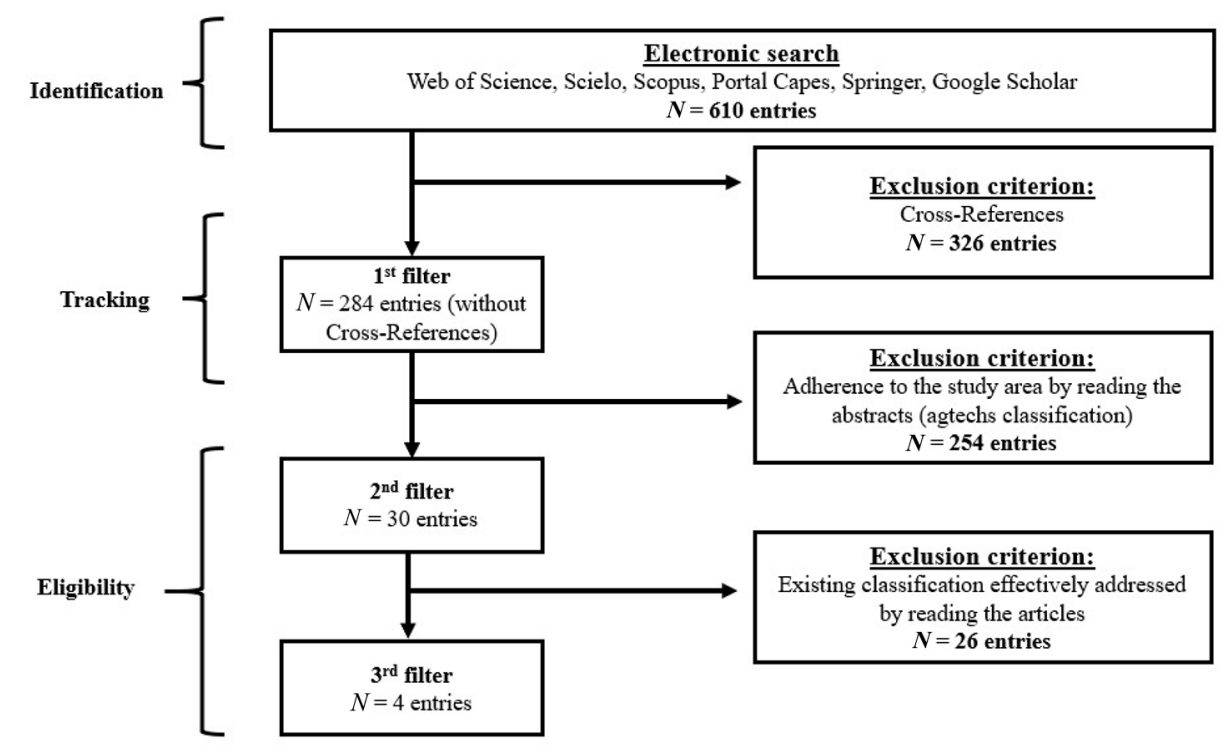

Source: By the authors 
Electronic devices and sensors; Machinery and equipment; Agricultural production; Marketing, processing and distribution; Consumer products, services and retail; Agricultural inputs, distribution and sales; and Unspecified. Figure 2 illustrates this classification model.

The second classification model was proposed by Dias, Jardim, and Sakuda (2019) and considers the segmentation of agtechs based on two dimensions. The first is linked to a classic agribusiness approach, developed at Harvard University in 1957, which correlates the production processes within the farm with upstream (activities before the production) and downstream (activities after the production) stages. The second dimension regards the operating market and technological field of these companies. This classification model offered 33 categories, divided as follows:

- Before the Gate (upstream): Laboratory analysis; Biological control; Shared economy; Fertilizers, inoculants and nutrients; Genomics and biotechnology; Animal nutrition and health; Seeds and seedlings and Financial services.

- Inside the Farm: Precision farming; Aquaculture; Content, education and social media; Image diagnosis; Residue and water management; Internet of things; Meteorology and irrigation; Machinery and equipment; Scouting; Remote sensing; Farm management; Telemetry and automation and UAV.

- After the Farm (downstream): Innovative foods and new food trends; Storage, infrastructure and logistics; Bioenergy and biodiversity; Consulting, acceleration and association; Plant factory and new planting forms; Industry 4.0; Autonomous store and retail management; E-grocery; Trading platform and sales marketplace; Online restaurant and meal kit; Food safety and traceability and Packaging system, environment and recycling.

Figure 3 presents the model proposed by Dias et al. (2019), with its classification categories.

Proposed by KPMG (2018), the third agtech classification model is linked to the activities developed in each agro-industrial sector and presents the following categories: Business management; Precision agriculture \& analytics; Animal management, Agroforestry; Robotics and drones; Agricultural inputs \& pest control; Ecologic \& disruptive farming; and Marketplaces. Figure 4 presents the characteristics and descriptions of each category.

The last classification model was proposed by Dutia (2014). According to him, this model was the precursor of the agtech classification systems. Basically, it focuses on the categorization of the agribusiness value chain, more specifically on the production chain.

The categories created by the author to classify agricultural startups were as follows: Technological inputs, with a subdivision into physical and informational inputs; Animal production; Crop production; Agricultural processing; and Manufacture and distribution. Figure 5 shows this model.

\begin{tabular}{|c|c|c|c|}
\hline Author & Title & $\begin{array}{l}\text { Year of } \\
\text { publication }\end{array}$ & \\
\hline $\begin{array}{l}\text { Graff, G. D.; Silva, F. F.; \& } \\
\text { Zilberman, D }\end{array}$ & $\begin{array}{l}\text { Venture Capital and the Transformation of Private R\&D for } \\
\text { Agriculture and Food }\end{array}$ & 2019 & \\
\hline Dias, C. N.; Jardim, F.; \& & Radar AgTech Brasil 2019: Mapeamento das Startups do Setor & 2019 & Table 1. \\
\hline $\begin{array}{l}\text { Sakuda, L. O } \\
\text { KPMG }\end{array}$ & $\begin{array}{l}\text { Agro Brasileiro } \\
\text { Agtech mining report: } 1 \text { semestre } 2018\end{array}$ & 2018 & Identification of \\
\hline Dutia, S. G & Agtech: Challenges and Opportunities for Sustainable Growth & 2014 & $\begin{array}{l}\text { entries that present } \\
\text { structured agtechs }\end{array}$ \\
\hline Source: By the authors & & & classification models \\
\hline
\end{tabular}




\section{INMR} 18,3

\section{4}

Figure 2.

Agtech classification model proposed by Graff et al. (2019)

\begin{tabular}{|l|}
\hline BUSINESS \& FINANCIAL \\
1. \\
RERVICES \\
Real Estate; Land \\
brokerage \\
Human Resource; Labor \\
Contracting, Training and \\
Education Services \\
3. $\begin{array}{l}\text { Financial Services; } \\
\text { investment }\end{array}$ \\
4. Insurance; Risk \\
Management
\end{tabular}

5. Industry Associations and advocacy

6. Economic development and reginal development organizations

7. "B2B" services or marketplaces

8. Publishing, catalogues, clients

9. Consulting, advisory services

10. Contract research services information for industry

\section{BIOTECH, GENETICS AND} HEALTH

1. "Online", "Website", "Web" or "Portal"; often "Platform" but not always

2. "B2B" or "B2C", but almost always in combination with another appropriate industry category

3. "Apps" or "Mobile", often in combination with Software, Data and IT category

SOFTWARE, DATA, AND IT

1. "Software" or "App"

2. "Data"

3. "Analytics" "Machine Learning"

5. "Blockchain" or "Distributed Ledger" "biotech"

2. Companies described as "genetics"

3. Breeding

4. Biological Control

5. Biopesticides

6. Biofertilizers, compost, biochar, other biological soil amendments

7. Microbial/microbiome

8. Animal health, including vaccines (but NOT feed additives)

9. Animal reproduction, such as sexing, artificial insemination
4. "Artificial intelligence" or

1. Companies described as

\section{CHEMICALS}

1. (Agro- or $\mathrm{Ag}$-) chemical manufacturing

2. Any of the "-icides", if not explicitly biological

3. Mention of a specific class of chemical compounds that characterize products

4. Inert materials with beneficial properties as soil additives

5. Nanomaterials

\section{ELECTRONIC DEVICES, SENSORS}

1. Smart or Automated

"Systems"

2. "Hardware"

3. Lighting or LED Systems

4. Control Systems

5. Robots, drones, unmanned or autonomous vehicles

\begin{tabular}{|ll|l}
\hline $\begin{array}{l}\text { UNSPECIFIED } \\
\text { 1. Unable to determine: Combined } \\
\text { industry/technology descriptions are } \\
\text { too general or missing altogether }\end{array}$ & $\begin{array}{l}\text { MACHINERY AND EQUIPMENT } \\
\text { 1. }\end{array}$ & $\begin{array}{l}\text { Manufacture of farm machinery or equipment } \\
\text { 2. }\end{array}$ \\
\hline
\end{tabular}

Actual operation of a farm or other production operation

2. Cultivation

3. Production

4. Often "provision of agricultural services"

5. Often mentions actual commodity produced

6. In combination with Marketing Processing category if vertical integrated business, such as livestock, oil palm

7. In combination with Marketing Processing category if fresh market, such as fruit, vegetable, produce

8. In combination with Marketing Processing category and CONSUMER category if "community supported agriculture (CSA)", "farm to table", "locally produced", etc.

\begin{tabular}{|c|c|}
\hline $\begin{array}{l}\text { MARKETING, PROCESSING AND DISTRIBUTION } \\
\text { 1. Post-harvest marketing, distribution, export/import, brokering } \\
\text { 2. Transportation, logistics } \\
\text { 3. Processing, milling a) animal slaughter, meat processing, meat } \\
\text { packing; b) grain milling, feed milling; c) oil pressing, } \\
\text { processing; d) cotton ginning; e) sawmills; f) ethanol plants } \\
\text { 4. Other fermentation, extraction, separation, purification. } \\
\text { 5. Food manufacturing } \\
\text { Farmers markets; "local" food marketing }\end{array}$ & $\begin{array}{l}\text { CONSUMER PRODUCTS, SERVICES, AND RETAIL } \\
\text { 1. Explicit mention of "consumer", "home", "household" } \\
\text { 2. Retail } \\
\text { 3. Specific product } \\
\text { 4. Marketing or distribution to final consumer } \\
\text { 5. Consumer connect to production/distribution } \\
\text { 6. Mention of "garden", gardening supplies, garden equipment }\end{array}$ \\
\hline
\end{tabular}

\section{AG INPUTS DISTRIBUTION AND SALES}

1. "Distributions", "sales", "retail", "wholesale”, "supply", "provision of range" of ag inputs including:

a) Seeds, plant starts; b) Ag chemicals, pesticides, fertilizers; c) Biological amendments; d) Animal feed; e) Animal health; f) Young live animal; g) Farm supplies and Aquaculture supplies; h) machinery and equipment; i) Parts and services

2. Small minority include "agricultural services" such as contract harvesting, piecework, agronomic consulting services, management

Although different, these classification models were created from empirical efforts and research analysis. According to Piedade (1977), a classification system consists of the division into groups or classes, considering their differences or similarities. This division provides the elements that allow the identification of a classification procedure: the organized and systematic formation of groups and the ordering of 


\begin{tabular}{|c|c|c|c|c|c|}
\hline \multicolumn{6}{|c|}{ BERFORE THE FARM } \\
\hline \multirow{2}{*}{$\begin{array}{l}\text { LABORATORY ANALYSIS } \\
\text { Startups that commercialize } \\
\text { and/or develop new } \\
\text { methods for laboratory } \\
\text { analysis of nutrient indices, } \\
\text { soil composition and } \\
\text { development of plants and } \\
\text { animals. }\end{array}$} & $\begin{array}{r}\text { BIOLO } \\
\text { Startups } \\
\text { and/ord } \\
\text { biological } \\
\text { or microsc }\end{array}$ & $\begin{array}{l}\text { ICAL CONTROL } \\
\text { hat commercialize } \\
\text { velop chemical and } \\
\text { ariants (macroscopic } \\
\text { ic) aimed at fighting }\end{array}$ & \multicolumn{2}{|c|}{$\begin{array}{l}\text { FINANCIAL SERVICES } \\
\text { Startups that provide financial } \\
\text { services, such as credit, barter } \\
\text { and securitization for rural } \\
\text { producers. }\end{array}$} & $\begin{array}{l}\text { ANIMAL NUTRITION AND HEALTH } \\
\text { Startups that commercialize and/or develop } \\
\text { new foods, drugs and nutrition and health } \\
\text { care in order to improve the development, } \\
\text { growth and immune system of animals. }\end{array}$ \\
\hline & tradition & nts. & \multirow{2}{*}{\multicolumn{2}{|c|}{$\begin{array}{l}\text { SHARED ECONOMY } \\
\text { Startups that provide } \\
\text { equipment and machinery for } \\
\text { rent and promote their } \\
\text { sharing among rural } \\
\text { producers. }\end{array}$}} & \multirow{2}{*}{$\begin{array}{l}\text { SEED AND SEEDLINGS } \\
\text { Startups that commercialize and/or develop } \\
\text { disruptive methods, processes and technologies } \\
\text { in the development of varieties of seeds and } \\
\text { seedlings, as well as in their multiplication, } \\
\text { germination and distribution methods. }\end{array}$} \\
\hline \multicolumn{3}{|c|}{$\begin{array}{l}\text { FERTILIZERS, INOCULANTS AND NUTRIENTS } \\
\text { Startups that commercialize and/or develop new fertilizers, } \\
\text { inoculants and nutrients in order to improve the development, } \\
\text { growth and immune system of plants. }\end{array}$} & & & \\
\hline \multicolumn{6}{|c|}{$\begin{array}{l}\text { GENOMICS AND BIOTECHNOLOGY } \\
\text { Startups that commercialize and/or develop plant breeding, technology for the scalable production of biological substances and define new uses for } \\
\text { these biological substances. }\end{array}$} \\
\hline \multicolumn{6}{|c|}{ INSIDE THE FARM } \\
\hline \multirow{2}{*}{$\begin{array}{l}\text { PRECISION FARMING } \\
\text { Startups that } \\
\text { commercialize and/or } \\
\text { develop technologies to } \\
\text { improve efficiency in the } \\
\text { use of inputs. }\end{array}$} & \multicolumn{2}{|c|}{$\begin{array}{l}\text { AQUACULTURE } \\
\text { Startups that operate in the fish, } \\
\text { crustacean and seafood sector }\end{array}$} & \multirow{2}{*}{\multicolumn{2}{|c|}{$\begin{array}{c}\text { CONTENT, EDUCATION \& } \\
\text { SOCIAL MEDIA } \\
\text { Startups that develop and } \\
\text { provide online platforms for the } \\
\text { dissemination of content, } \\
\text { information and best agricultural, } \\
\text { agronomic and livestock } \\
\text { practices, in order to empower } \\
\text { and bring rural producers closer } \\
\text { together. }\end{array}$}} & $\begin{array}{l}\text { IMAGE DIAGNOSIS } \\
\text { Startups that develop and provide platforms } \\
\text { and algorithms for the identification of } \\
\text { patterns through spectrometry. }\end{array}$ \\
\hline & \multicolumn{2}{|c|}{$\begin{array}{l}\text { INTERNET OF THINGS (loT) } \\
\text { Startups that develop and } \\
\text { provide equipment and sensors } \\
\text { capable of communicating with } \\
\text { each other. }\end{array}$} & & & $\begin{array}{l}\text { RESIDUE AND WATER MANAGEMENT } \\
\text { Startups that commercialize and/or develop } \\
\text { equipment, methods and processes to } \\
\text { improve residue and water management. }\end{array}$ \\
\hline \multicolumn{3}{|c|}{$\begin{array}{l}\text { MACHINERY \& EQUIPMENT } \\
\text { Startups that commercialize and/or develop machines and } \\
\text { equipment that are disruptive in technology or usability. }\end{array}$} & \multicolumn{2}{|c|}{$\begin{array}{l}\text { Startups that develop and } \\
\text { provide unmanned aerial } \\
\text { vehicles, as well as vehicles and } \\
\text { support for boarding different } \\
\text { types of equipment. }\end{array}$} & $\begin{array}{l}\text { SCOUTING } \\
\text { Startups that develop and provide platforms } \\
\text { and equipment for continuous and integrated } \\
\text { monitoring of relevant aspects for } \\
\text { productivity and decision making in the field. }\end{array}$ \\
\hline $\begin{array}{l}\quad \text { TELEMETRY \& } \\
\text { AUTOMATION } \\
\text { Startups that commercialize } \\
\text { and/or develop equipment and } \\
\text { algorithms for the capture, } \\
\text { consolidation and automation } \\
\text { of processes. }\end{array}$ & \multicolumn{2}{|c|}{$\begin{array}{l}\text { REMOTE SENSING } \\
\text { Startups that develop and } \\
\text { provide online platforms to } \\
\text { assist the rural producer in the } \\
\text { control, knowledge and } \\
\text { delimitation of the farm. }\end{array}$} & \multicolumn{3}{|c|}{$\begin{array}{l}\text { METEOROLOGY \& IRRIGATION } \\
\text { Startups that develop and provide equipment, methods and processes to improve } \\
\text { the predictability of rainfall, as well as bring better management and efficiency to } \\
\text { the irrigation process. }\end{array}$} \\
\hline \multicolumn{6}{|c|}{$\begin{array}{l}\text { FARM MANAGEMENT } \\
\text { Startups that develop and provide online platforms to assist the rural producers in management, organization and decision making. }\end{array}$} \\
\hline \multicolumn{6}{|c|}{ AFTER THE FARM } \\
\hline \multirow{2}{*}{\begin{tabular}{|c|} 
AUTONOMOUS STORE \\
AND RETAIL \\
MANAGEMENT \\
Startups that develop and \\
provide processes, methods \\
and technologies for \\
automating stores and \\
assisting retail \\
management.
\end{tabular}} & \multirow{2}{*}{\multicolumn{2}{|c|}{$\begin{array}{l}\text { PACKING, ENVIRONMENT } \\
\text { AND RECYCLING SYSTEMS } \\
\text { Startups that develop and provide } \\
\text { new processes, methods and } \\
\text { technologies for packaging in } \\
\text { order to mitigate negative impacts } \\
\text { on the environment and facilitate } \\
\text { recycling. }\end{array}$}} & \multirow{2}{*}{\multicolumn{2}{|c|}{\begin{tabular}{|c|} 
STORAGE, \\
$\frac{\text { INFRASTRUCTURE \& }}{\text { LOGISTICS }}$ \\
Startups that develop and \\
provide new processes, methods \\
and technologies for storage and \\
transportation of commodities \\
and food.
\end{tabular}}} & $\begin{array}{l}\text { BIOENERGY AND BIODIVERSITY } \\
\text { Startups that develop and provide new } \\
\text { processes, methods and technologies for the } \\
\text { production of bioenergy and/or protection of } \\
\text { biodiversity. }\end{array}$ \\
\hline & & & & & \multirow{2}{*}{$\begin{array}{l}\text { TRADING PLATFORM \& MARKETPLACE } \\
\text { Startups that develop and provide online } \\
\text { platforms for the commercialization of inputs } \\
\text { and commodities. }\end{array}$} \\
\hline \multirow{2}{*}{\multicolumn{4}{|c|}{$\begin{array}{l}\text { PLANT FACTORY AND NEW PLANTING FORMS } \\
\text { Startups that develop and provide new processes, methods and } \\
\text { technologies for the production of crops in urban or internal areas. }\end{array}$}} & \multirow{3}{*}{$\begin{array}{l}\text { INDUSTRY 4.0 } \\
\text { Startups that develop } \\
\text { and provide new } \\
\text { processes, methods and } \\
\text { technologies in order to } \\
\text { increase efficiency in the } \\
\text { use of resources in the } \\
\text { food sector. }\end{array}$} & \\
\hline & & & & & $\frac{\text { CONSULTING, ACCELERATION AND }}{\text { ASSOCIATION }}$ \\
\hline \multirow{2}{*}{\multicolumn{2}{|c|}{$\begin{array}{l}\text { ONLINE RESTAURANT \& MEAL KIT } \\
\text { Startups that develop and provide online } \\
\text { platforms for the sale of products and } \\
\text { food ready for consumption or just } \\
\text { needing to be heated, with the possibility } \\
\text { of monthly subscription. }\end{array}$}} & \multirow{2}{*}{\multicolumn{2}{|c|}{$\begin{array}{l}\text { E-GROCERY } \\
\text { Startups that develop and } \\
\text { provide online platforms for } \\
\text { the sale of unprepared } \\
\text { products and food, with the } \\
\text { possibility of monthly } \\
\text { subscription. }\end{array}$}} & & $\begin{array}{l}\text { acceleration and association services for rural } \\
\text { producers, as well as startups active in the } \\
\text { sector. }\end{array}$ \\
\hline & & & & $\begin{array}{r}\text { INNOVATIVE } \\
\begin{array}{r}\text { Startups that develop ar } \\
\text { with the incorporation } \\
\text { new use of ingr }\end{array} \\
\end{array}$ & $\begin{array}{l}\text { EOOD AND NEW FOOD TRENDS } \\
\text { and provide food with better nutritional indexes, } \\
\text { n of healthier substitute ingredients and with a } \\
\text { redients already used in other products. }\end{array}$ \\
\hline rtups that develop and & de techno & $\begin{array}{l}\text { FOOD } \\
\text { es that increase th }\end{array}$ & ETY \& & $\frac{\text { RACEABILITY }}{d \text { shelf-life of food and }}$ & sist in the traceability of ingredients used in \\
\hline
\end{tabular}

Source: Dias, C. N., Jardim, F., \& Sakuda, L. O. (2019)

\section{Brazilian agricultural startups}

Figure 3.

Agtech classification model proposed by

Dias et al. (2019) 
INMR

18,3

246

Figure 4.

Agtech classification model proposed by KPMG (2018)

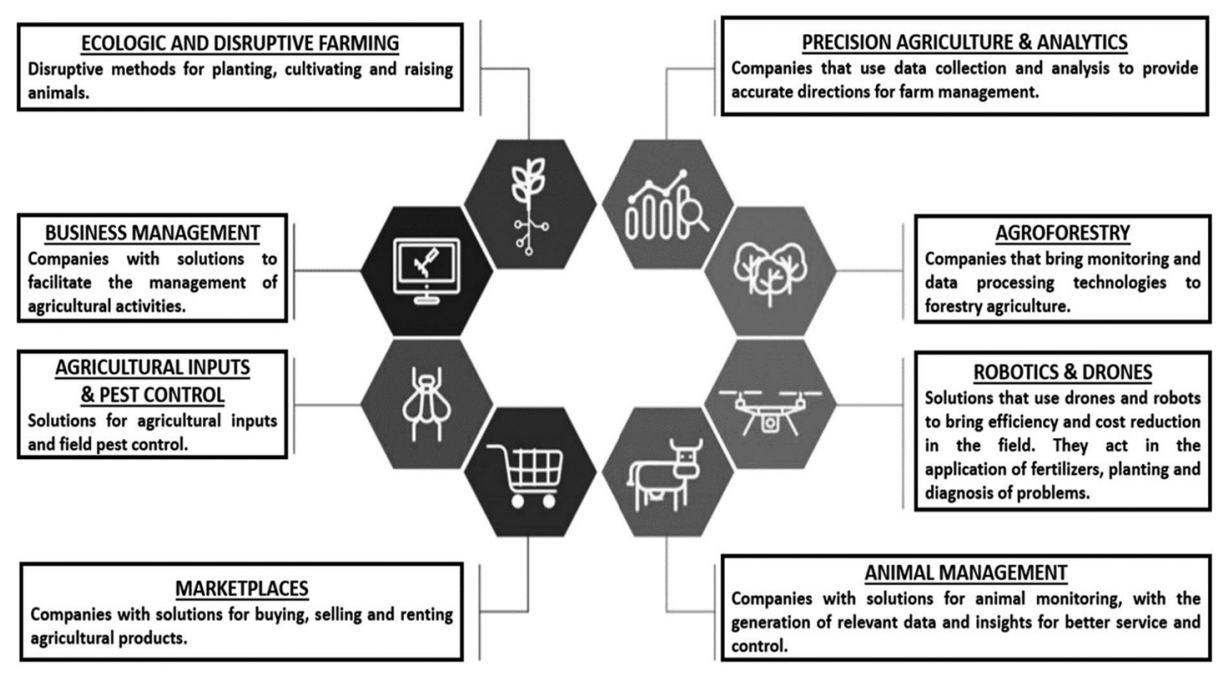

Source: KPMG (2018). Agtech mining report

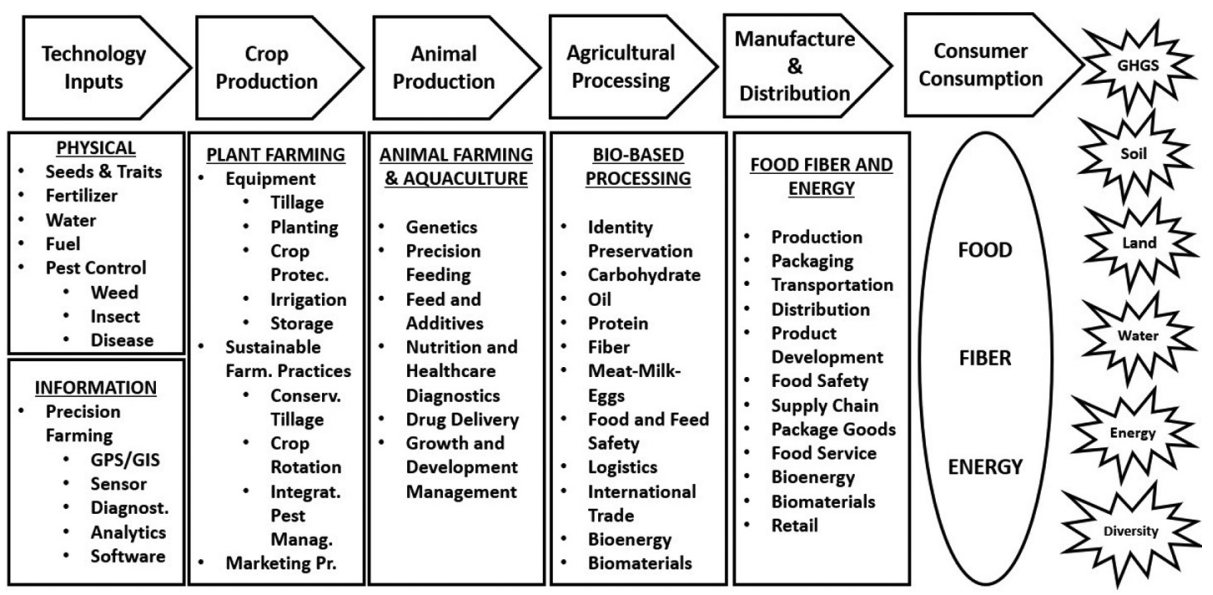

Source: Dutia, S. G. (2014). Challenges and Opportunities for Sustainable Growth

certain data sets based on shared characteristics (Araújo, 2006). In addition to understanding the agribusiness chain, it is important that the proposed categories have density and depth. According to Gardner (1996), the classification based on categorization depends on the degree of sharing crucial characteristics of the peripheral prototypes with the central one. The greater the degree of sharing, the greater the density of the categories generated. And, consequently, the better the classification will represent the reality. 


\section{Field research results}

In each thinking aloud session, an additional task was proposed to each participant. The task consists of preparing a list of phrases and words that should qualify the most and least adherent system to the Brazilian context. The sentences were submitted to a lexicographic analysis, with the aid of IRAMUTEQ®.

Figure 6 shows the 15 most cited words in the least adherent classification to the Brazilian context, which were: "Dutia", "generic", "application", "no", "agribusiness", "low" (both male and female words in Portuguese), "potential", "basic", "chain", "categories", "classification", "poor", "reality", "you”.

When asked which classification would be the least adherent to the Brazilian context, all participants mentioned the classification of Dutia (2014). The word "generic" was used by $100 \%$ of the participants; "low" (both male and female words in Portuguese) and "application" were cited by $60 \%$ of the respondents; and "poor" and "basic" by $40 \%$ of them.

According to Santos, Ferreira, Barros, and Prates (2013), problems of generality can affect the usability of the classification system. A generic system causes failures in the understanding and decoding of the message transmitted by each category, in addition to little practical application.

Figure 7 shows the 17 most cited words in the most adherent classification to the Brazilian context, which were "Dias", "Jardim", "Sakuda", "precision", "sector", "broad”, "agricultural”, "benefits", "categorization"; "comprehensiveness", "categories", "understand", "of", "effort", "in", "by", "brings".

When asked about which classification would be the most adherent to the Brazilian context, $80 \%$ of the participants mentioned the classification proposed by Dias et al. (2019). The word "precision" was mentioned by $100 \%$ of the participants, while "broad/comprehensiveness" was mentioned by $75 \%$ of the respondents, and "effort" by $50 \%$ of them.

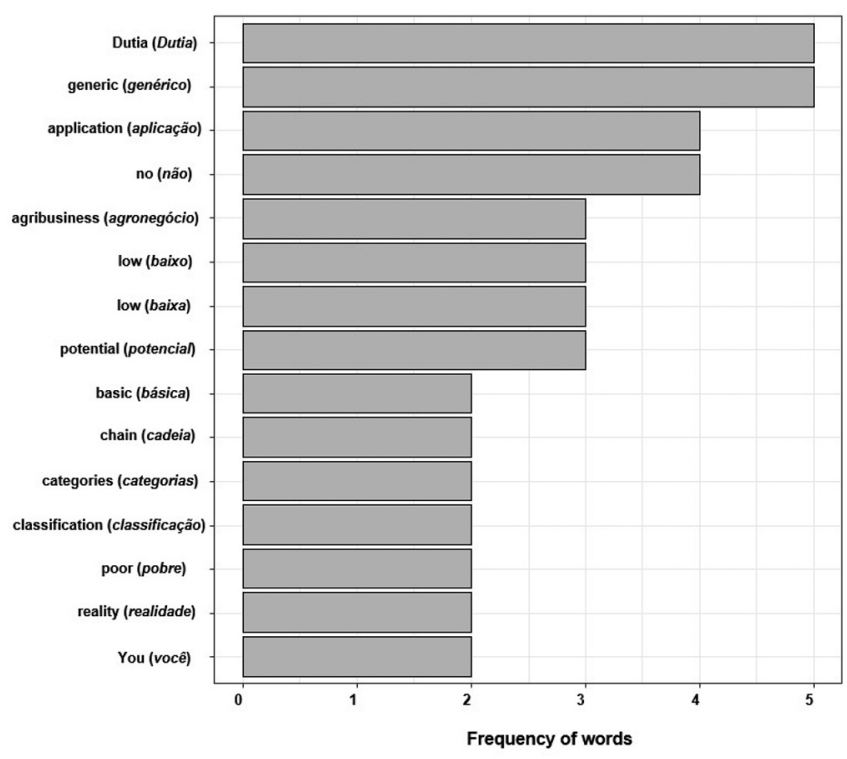

Note: Portuguese words in brackets

Source: By the authors

Figure 6.

Frequency of the 15 most cited words in the least adherent classification to the Brazilian context 


\section{INMR}

18,3

\section{8}

Figure 7.

Frequency of the 17 the most cited words in the most adherent classification to the Brazilian context

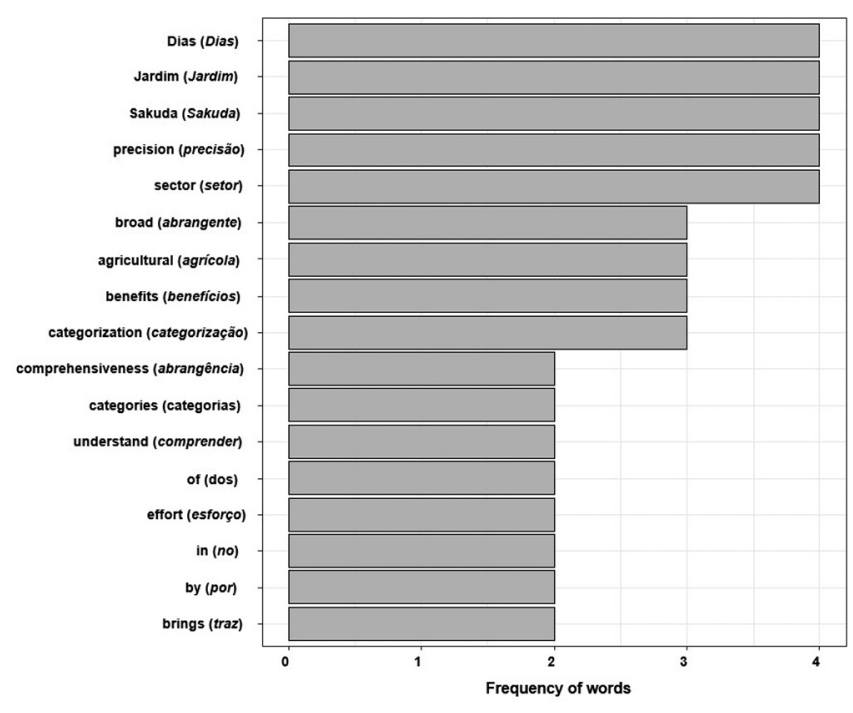

Note: Portuguese words in brackets Source: By the authors

According to Apostel (1963), a classification system should have a finite number of divisions and classes within each division. Furthermore, this finite number should cover all possibilities of entries of the system to be referenced.

All classification models obtained in the LSR - Graff et al. (2019), Dias et al. (2019); KPMG (2018) and Dutia (2014) - were analyzed considering the theoretical foundations of the classification, i.e. whether these classification models were based on the separation of groups according to differences or similarities; and whether the categories presented density and depth. This analysis was based on the content analysis of the thinking aloud sessions.

Participants were identified by the letter E, followed by Arabic numerals. Table 2 shows the positive and negative aspects of each classification model.

\begin{tabular}{|c|c|c|}
\hline Model & Positive aspects & Negative aspects \\
\hline Graff et al. (2019) & $\begin{array}{l}\text { - Rationality of categories } \\
\text { - Depth of categories }\end{array}$ & - Superposition of categories \\
\hline Dias et al. (2019) & $\begin{array}{l}\text { - Comprehensiveness of the model; } \\
\text { - Density of categories. } \\
\text { - Depth of categories }\end{array}$ & - Segmentation of categories \\
\hline KPMG (2018) & - Rationality of categories & $\begin{array}{l}\text { - Superposition of categories; } \\
\text { - Density of categories; } \\
\text { - Depth of categories }\end{array}$ \\
\hline Dutia (2014) & - Rationality of categories & $\begin{array}{l}\text { - Superposition of categories; } \\
\text { - Density of categories; } \\
\text { - Depth of categories. } \\
\text { - Comprehensiveness of the model }\end{array}$ \\
\hline
\end{tabular}

Source: By the authors

Table 2.

Positive and negative aspects of each agtech classification model 
Thus, the positive and negative points were discussed according to the following criteria: rationality of categories; depth of categories; density of categories; comprehensiveness of the model; superposition of categories; and segmentation of categories. Each of these criteria will be explained in more detail below.

\subsection{Rationality of categories}

According to Manhein (1942) and Simon (1997), rationality is defined as several organized measures that lead to a previously defined objective, by using the most sundry components of these measures. Such measures will have the best conditions when they coordinate the means efficiently to achieve the initial objective.

In classification systems, rationality is important because it supports the formation of systematized and organized groups. It enables the proposed categories to unveil a conscience; hence, the meanings of each description are deliberately understood by individuals.

The model proposed by Graff et al. (2019) has a positive aspect regarding the rationality of the categories. According to the participant of this research [E2], positive rationality was found when there was a concern to create categories based on technological aspects. Currently, technology is responsible for increasing the productivity rates of Brazilian agriculture:

"[...] in this classification system there is a rationalization of categories through a different technological bias. It was not considered just a categorization of input, processing and output data, but a thought to understand their motivations and reasons." [E2]

[E3] and [E5], in turn, believe that this model acts rationally when, in the creation of categories, it presents an effort of reflection and thinking:

"When creating a category, it's not just because something is [...] different that I create a category. It is necessary to seek a rational and motivational effort that brings the need for separation." [E3]

"When reflecting on the construction of this classification model, it is evident that the authors tried to follow a guiding line that permeated the entire systematization. [...] this system is a robust, [...] rational and predictive construction." [E5]

The model proposed by the consultancy firm KMPG (2018), in turn, brings the rationality of the categories as a positive aspect because it adopts structural characteristics of agricultural thinking. According to [E1] and [E2], this rationality is achieved by this model:

"[...] the positive point in this classification is the analytical input. It did not focus on the issue of links in the agro-industrial chain. Although they are present, they are not the focus." [E1]

"Although it is not so complete, when presenting the classification considering aspects before, inside and after the farm, it creates categories with rationality, i.e., it considers the main points of agribusiness." [E2]

According to [E5], Dutia's model (2014) has a positive aspect in relation to rationality, as it seeks to develop the categories based on the synergism between agribusiness value chain and technological application:

"I understand [...], that all categories are related to technological application. I think this is essential, if you are talking about startup, then it is consistent with the key concept." [E5]

According to the participants of the thinking aloud sessions, none of the models lacked rationality. This shows that, although they have some deficiencies, the categories were created from an awareness of productive activities and from the needs of farmers. 


\section{INMR}

18,3

\subsection{Depth of categories}

According to Houaiss (2001), depth is an attribute of deep. Deep refers to something farreaching; very important. For Pozzebon, Freitas, and Petrini (1999), the depth of categories comprises the richness and magnitude of detailing the contents described by them. The greater the depth and volume of information within the categories, the more easily they are understood and the more beneficial and advantageous their use are (Pipino, Yang, \& Wang, 250 2002).

Depth has a positive aspect in the classification models developed by Dias et al. (2019) and Graff et al. (2019). For [E2], the depth occurs in the model of Dias et al. (2019) as it seeks to establish patterns of agricultural activities in the entire agribusiness chain in the creation of the categories. On the other hand, [E1] believes that the model of Graff et al. (2019) has depth, as the categories were built in detail. The speeches below demonstrate these opinions:

"This classification presents a good spectrum, they were concerned with the parameterization of activities." [E2]

"The positive points of this classification are the depth and the number of categories [...]. And I found the depth of the information very important [...]. I think this is a strong point because it makes it easier to know where to insert each startup." [E1]

Negative aspects in relation to depth were found in the classification models proposed by KPMG (2018) and Dutia (2014). For [E2] and [E4], the KPMG model has low depth, which may be the result of a superficial view of the agribusiness chain. In his speech, [E1] highlights the low depth of the model developed by Dutia (2014), possibly due to a simplified view of the agricultural activity. Below are the respective arguments:

"The classification is interesting, but it could be a little more precise and deeper. The complete agribusiness chain still needs to be understood." [E2]

"This macro classification looks like a classification made by those who are not from the area. It seems to have been created by an administrator, external to the agribusiness area, and who tries, without knowing the particularities, to make a classification." [E4]

"The definition of the categories is arbitrary, each researcher can insert the startup in whatever category he/she wants, since the categories are simplistic." [E1].

\subsection{Density of categories}

According to Houaiss (2001), the word dense is defined as something that has a large mass in relation to the bounded volume. Density, on the other hand, refers to the level and amount of information in relation to the decision space.

In a model, the created category should present density in the information to allow the user an easy reading and understanding of their contents. Furthermore, density of categories properly guide the search for information or the resolution of problems in question (Gamez, 1998).

Density has a positive aspect in the classification model developed by Dias et al. (2019). According to [E4], these authors sought to combine similar characteristics, creating a welldefined and more usual model:

"I think there has been a great advance on the issue of creating denser categories, which add similarities. This makes it smoother, helping in the startup's classification process [. . .]." [E4] 
The models developed by KPMG (2018) and Dutia (2014) presented negative aspects regarding density. According to the participant [E4], the KPMG (2018) model, although rational, presents an incomplete consideration on the density of information presented in each category. This same participant indicates that Dutia's model fails to consider the density criterion because it focuses on farm activities and not in agribusiness as a whole. The following segments exemplify the opinion of [E4] on the respective models:

"Creation requires reflection to add density, [. . . it is not just to exclude the different, but to group the singularities. It seems to me that this classification did not bring that." [E4]

"If we think about a categorization of startups for farms or production systems, perhaps it will contemplate them [...]. So we are not talking about startups for agribusiness or for the value chain." [E4]

\subsection{Comprehensiveness of the model}

According to Tristão, Fachin, and Alarcon (2004), the definition and choice of the classes that constitute a classification model are related to the comprehensiveness and needs of use for each model.

In classification models, groups are created, whose information ranges from the most comprehensive (basic classes) to the most specific concepts (focused classes) (Ranganathan, 1967).

The comprehensiveness in classification models can be understood as the amplitude that a given category or class has in relation to the total links. The more comprehensive the classification model, the greater its importance to represent the analyzed environment and the greater its usability.

According to the participant [E1], the model developed by Dias et al. (2019) has a positive aspect regarding the comprehensiveness of the model, as it can be used by several actors, who may have different domains within agribusiness:

"[...] you can provide a typology that can be widely used, from students [...] to doctors. In addition, it can be a great reference for investors to do market research, to decide whether to invest or not." [E1]

[E3] and [E4] addressed the negative aspect in relation to the comprehensiveness of Dutia's model (2014). According to these participants, when trying to be comprehensive, the model impoverishes the description of the categories, which can lead to failures in the classification:

"[...] the categorization is very broad, [ . . . it would be necessary to detail more [...]. Depending on the startup, it can be classified into 3 distinct categories, with the classification as a whole presenting 5 categories. There is lack of focus." [E3]

"[...] comparatively, it was the poorest in terms of comprehensiveness. We may have more difficulties using it." [E2]

\subsection{Superposition of categories}

In classification models, the superposition is the intersection between two conceptual information. It occurs when substantial information, which characterizes a certain category, also appears in a different category. There is a conceptual inclusion relationship between them (Carlan \& Medeiros, 2011). 
INMR

18,3

According to Apostel (1963), the categories should be exhaustive, i.e. they must cover the entire extension of the domain to be classified. They should never be empty or superposed.

The superposition of categories presented a negative aspect in the models proposed by Graff et al. (2019), KPMG (2018) and Dutia (2014).

For [E4], the model of Graff et al. (2019) presents 12 major classifying groups and, in most of them, the substantial information that would determine the category is the same:

"[...] my criticism would be in the sense that [...] we still have a large superposition of things, which seem to me to be the same things when I read." [E4]

When faced with the model developed by KPMG (2018), [E3] finds few categories and, even so, they present the same substantial information:

"[...] my concern with this classification is the number of categories created. Its low number causes a superposition of categories. It gets confusing and leaves room for misclassification." [E3]

For [E3] and [E1], Dutia's model (2014) presents superposed categories, which would hinder the correct classification. The following fragments of the speeches point to this characteristic:

"[...] in that sense, it seems to me that when you are framing agtechs, you may have a great difficulty in classifying them, because a particular agtech can fit into all categories." [E1]

“[... ] this one I think has a large superposition." [E5]

\subsection{Segmentation of categories}

According to Spiteri (1998), segmentation uses global information resources to obtain specificity of the subjects and, therefore, create classes or categories that adhere to the studied reality. The segmentation process of informational content affects the user, whether in the interpretation of information or in the use of classification systems (Azevedo, 2008).

Although it is important to segment to bring specificity, classifications with many categories, which are too segmented, can be inaccurate representations of the information in the studied area (Furgeri, 2006).

The model proposed by Dias et al. (2019) presented a negative aspect regarding this component, as many categories were used in the development of the model. The participants [E2], [E3], [E4] and [E5] showed discomfort in using a classification model with an excess of categories.

"[. . . ] too much segmented, that's my main point. The model segmented a lot and at the same time it did not segment correctly." [E2]

“[... ] this classification, for God's sake, is too much information.” [E3]

“[...] I won't even have the patience to read everything. You create categories exactly to help our understanding, but when you have a classification with more than 30 categories, it doesn't seem like an appropriate classification." [E4]

"[. . . I I believe that the volume of categories tends to cover, but at the same time, this large volume can generate specificities above the ideal [...].” [E5]

Thus, similarly to what was observed for the superposition of categories, there were no positive aspects mentioned in this topic by the participants in the thinking aloud sessions. 


\section{Proposition of a model to categorize agricultural startups (agtechs)}

Considering the positive and negative aspects pointed out in the thinking aloud sessions, a new classification model for Brazilian agtechs was proposed, as shown in Figure 8.

The model presented has its centrality based on the links of the agribusiness production chain (supplies and equipment, before planting, production, post-production and consumption), on the operational production processes (plant, animal and forestry) and on the peripheral production services (support and regulation services). This centrality allows the model to absorb positive aspects of rationality.

The rationality in the proposed model means that the services offered by each agtech are linked to a specific agricultural activity routine, considering that each stage has a service with greater demand and/or greater impact.

Similarly, rationality is considered in this new model when proposing groups according to the operational production processes and peripheral production services. With the creation of these categories, the model seeks to better target the service provided by agtechs with their specific customers, shortening the search time for the best service provider.

Considering the depth of categories, the proposed model was based on the binomial "links in the production chain" and "operational production processes". This binomial allowed the description elaborated in each created category to present the necessary depth for the agtechs (insertion in the category that represented the majority of the services offered by the agtech or those with the greatest impact on its routine) and consumers (understanding of the service offered).

Regarding the comprehensiveness, the model proposed in this article has an amplitude that covers the entire agricultural production chain. Its configuration allows the separation of the agtechs that provide services in the initial stage of the operational production process (supplies and equipment category) from those that provide services to the final consumer (consumption category).

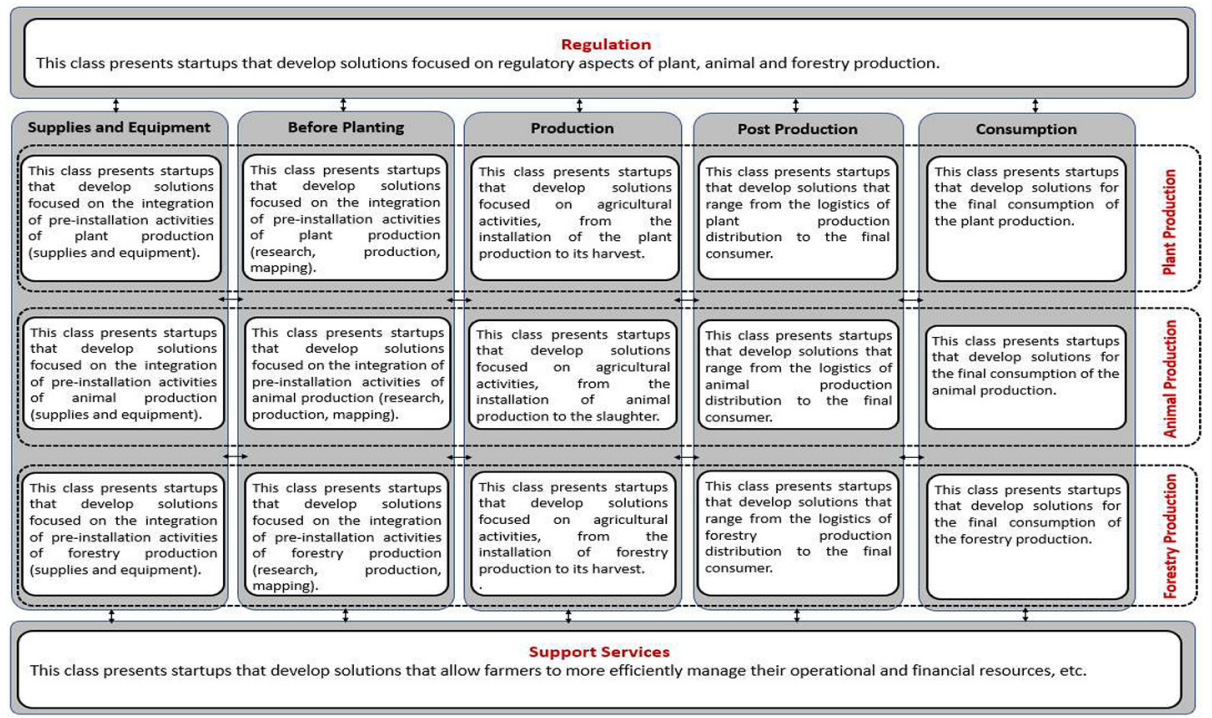

Source: By the authors

\section{Brazilian agricultural startups}

253

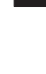


INMR 18,3

The last positive aspect used to compose the proposed model was density. Density refers to the volume of information in relation to the decision space. The model developed in this article sought to create categories that provide a satisfactory amount of information for the decision process of both the agtechs and the users of the model.

Regarding the negative points of the models found in the literature, the proposed model tried to reduce the superposition of categories and the excessive segmentation. This reduction was possible by the creation of a model whose centrality was obtained by the trinomial "links in the production chain", "operational production processes" and "peripheral production services", which allows the categorization necessary to cover the entire agricultural system.

\section{Conclusions}

The objective of this article was to conduct a systematic literature review (SLR), which sought to raise the main classification systems adherent to Brazilian context of agtechs, as well as to propose a new classification system. However, there was no intention to exhaust all debates about classifying Brazilian agtechs.

The contribution of this study was to point out what is currently being developed in relation to the classification models, their adherence to the Brazilian context, as well as the positive and negative points in the development of models applied to agribusiness. At the end of this contribution, it was possible to present a model that, after validation, can be another alternative to guide the classifiers inserted in agricultural systems.

The four classification models resulting from the SLR passed the scrutiny of researchers with business expertise in the agro-industrial systems, which allowed a critical view of their negative and positive aspects.

The main aspects raised by the researchers who participated in the thinking aloud sessions were rationality, density, depth, superposition and segmentation of the categories and comprehensiveness of the models.

Based on the lexicographic and content analyzes of the thinking aloud sessions, the model developed by Dutia (2014) was considered the least adherent to the Brazilian context, as it presented superposed categories, low density and depth, in addition to the low comprehensiveness of the model. The model developed by Dias et al. (2019), in turn, was the most effective in classifying Brazilian agtechs. The main positive characteristics of this system were the wide comprehensiveness of the model and the high density and depth of the categories.

Regarding the practical applications, this work can support researchers in the search for greater knowledge on this subject, as it highlights the current knowledge on agtech classification models.

\subsection{Future research}

After completing this SLR and given the findings of this article, we can suggest some guidelines for future work. The first refers to the continuation of this study, through the submission of the models proposed by Dutia (2014), KPMG (2018), Graff et al. (2019) and Dias et al. (2019) to the scrutiny of other actors involved in the innovation ecosystem of the agricultural sector, such as angel investors, students and entrepreneurs who perceives agribusiness from another perspective. New points of view are important, as they can bring new aspects that will contribute to the improvement, application and usability of these models. As a field research method, the application of the thinking aloud verbal protocol is suggested.

The second driver would be the proposition of an academic investigation to verify which aspect, among those presented in this article (rationality, density, depth, superposition and segmentation of categories and comprehensiveness of the models), have the greatest 
influence, both in the process of creating the model and in the success and/or failure of the adoption of the classification model created. This type of investigation seems to be relevant because, in some situations, authors may choose an aspect that does not have the greatest impact in the context to be classified. As a field research method, it is suggested to carry out a quantitative-type survey, where weight is attributed to each aspect studied, through scales ranging from (1) little important to (5) extremely important.

A third driver for future work would be to conduct a research to validate the model proposed in this article. A model is a simplified representation of a real system and, therefore, needs to be validated (mainly its components), so that there is no doubt about its representation and applicability. Initially, it is suggested to apply this validation to the same participants who collaborated with this article. In a second step, it is necessary to seek the opinion of other actors in agribusiness. As a field research method, the thinking aloud protocol is again suggested.

\section{References}

AgFunder (2019). AgriFood Tech Investing Report - 2018 (San Francisco). Recuperado em 16 de julho de $2019 \mathrm{em}$. Retrieved from https://research.agfunder.com/2018/AgFunder-Agrifood-Tech-InvestingReport-2018.pdf

Apostel, L. (1963). Le problème formel des classifications empiriques, Bruxelles: Éditions J. Duculot S.A. Gembloux.

Araújo, C. A. A. (2006). Fundamentos teóricos da classificação. Revista Eletrônica de Biblioteconomia e Ciência da Informação, 2, 1117-140, https://doi.org/10.5007/1518-2924.2006v11n22p117

Associação Brasileira de Startups [ABStartups] (2017). Radiologia das startups brasileiras. Recuperado em 17 de julho de 2019 em. Retrieved from https://abstartups.com.br/PDF/radiografia-startupsbrasileiras.pdf

Azevedo, C. X. (2008). A abordagem do conceito como uma estrutura semiótica. TransInformação, 20(1), 47-58. https://doi.org/10.1590/S0103-37862008000100004

Bardin, L. (2011). Análise de conteúdo, São Paulo: Edição 70.

Barros, J. R. M. (2017). A indústria e o agronegócio brasileiro. Recuperado 15 de julho de $2019 \mathrm{em}$. Retrieved from https:/iedi.org.br/media/site/artigos/20180703-a_industria_e_o_agronegocio_ brasileiro.pdf

Bécue-Bertaut, M. (2019). Textual statistics with $R$ (1st editio), doi:https://doi.org/10.1201/ 9781315212661.

Bellman, R. E. (1978). An introduction to artificial intelligence: Can computers think?, San Francisco: Boyd \& Fraser Publishing Company.

Blank, S., \& Dorf, B. (2012). The startup owner's manual: The step-by-step guides for building a great company, Vol. 1, Pescadeiro, CA, USA: K\&S Ranch Publishing Division.

Carlan, E., \& Medeiros, M. B. B. (2011). Sistemas de organização do conhecimento na visão da ciência da informação. Revista Ibero-Americana de Ciência Da Informação, 4(2), 53-73. doi: https://doi.org/ 10.26512/rici.v4.n2.2011.1675.

Casteleiro, J. M. (2001). Dicionário da lingua Portuguesa contemporânea, Lisboa: Academia das Ciências de Lisboa e Editorial Verbo.

Center for Advanced Studies on Applied Economics [CEPEA]. (2018). Relatório PIBagro - Brasil 2018. Retrieved from https://www.cepea.esalq.usp.br/br/pib-do-agronegocio-brasileiro.aspx

Costa, A. P. N., \& Leandro, L. A. L. (2016). O atual cenário das micros e pequenas empresas no brasil. Anais do XIII simpósio de excelência em gestão tecnológica, resende, Rio De Janeiro, Brasil. Retrieved from https://www.aedb.br/seget/arquivos/artigos16/14924134.pdf 
INMR 18,3

Crossan, M. M., \& Apaydin, M. (2010). A Multi-Dimensional framework of organizational innovation: A systematic review of the literature. Journal of Management Studies, 47(6), 1154-1191. https://doi. org/10.1111/j.1467-6486.2009.00880.x

Deichmann, U., Goyal, A., \& Mishra, D. (2016). Will digital technologies transform agriculture in developing countries? Agricultural Economics, 47(S1), 21-33. https:/doi.org/10.1111/agec.12300

Dias, C. N. Jardim, F., \& Sakuda, L. O. (2019). Radar AgTech Brasil 2019: Mapeamento das startups do setor agro brasileiro. Embrapa, SP Ventures e Homo Ludens: Brasília e São Paulo. Retrieved from www.radaragtech.com.br

Dutia, S. G. (2014). Agtech: Challenges and opportunities for sustainable growth. Innovations, 9(1-2), 161-193. https://doi.org/10.1162/inov_a_00208

Ericsson, K. A., \& Simon, H. A. (1993). Protocol analysis: Verbal reports as data (rev. Ed), Cambridge: MIT Press.

Es, H. M., Woodard, J. D., Glos, M., Chiu, L. V., Dutta, T., \& Ristow, A. (2016). Digital agriculture in New York, NY state: Report and recommendations, New York, NY: Cornell University.

Furgeri, S. (2006). Representação de informação e conhecimento: estudo das diferentes abordagens entre a ciência da informação e a ciência da computação. Dissertação de Mestrado, Pontifícia Universidade Católica de Campinas, Campinas, SP, Brasil.

Gamez, L. (1998). Manual do avaliador: Técnica de inspecção de conformidade ergonómica de software educacional, Braga: Universidade do Minho.

Gardner, H. (1996). A nova ciência da mente: Uma história da revolução cognitiva, São Paulo: EDUSP.

Graff, G. D., Silva, F. F., \& Zilberman, D. (2019). Venture capital and the transformation of private R\&D for agriculture and food. Economics of research and innovation in agriculture, Cambridge: National Bureau of Economic Research. In:

Greenacre, M. J. (2010). Correspondence analysis. Wiley Interdisciplinary Reviews: Computational Statistics, 2(5), 613-619. https://doi.org/10.1002/wics.114

Guilhoto, J. J. M., Silveira, F. G., Ichihara, S. M., \& Azzoni, C. R. (2006). A importância do agronegócio familiar no Brasil. Revista de Economia e Sociologia Rural, 44(3), 355-382. https://doi.org/ 10.1590/S0103-20032006000300002

Houaiss, A. (2001). Dicionário houaiss da língua Portuguesa, Rio de Janeiro: Editora. Objetiva.

Brazilian Institute of Geography and Statistics [IBGE]. (2018). Contas nacionais trimestrais - 4T 2018. Retrieved from https://sidra.ibge.gov.br/tabela/2072\#resultado

Kitchenham, B., \& Charters, S. (2007). Guidelines for performing systematic literature reviews in software engineering, School of Computer Science and Mathematics. Keele University.

KPMG. (2018). Agtech mining report - 1 semestre 2018. Retrieved from https://assets.kpmg/content/ dam/kpmg/br/pdf/2018/06/br-agtech-mining-report-2018.pdf

Malik, K. (2013). London is special, but not that special. New York Times, 29 September, SR5 (New York Edition).

Manhein, K. (1942). Libertady planificación social, México: Fondo de cultura econômica.

Manne, G., \& Stout, K. (2017). A brief assessment of the procompetitive effects of organizational restructuring in the Ag-Biotech industry. ICLE Antitrust \& Consumer Protection Research Program, 1-29. https://doi.org/10.2139/ssrn.3405711

Massruhá, S. M. F. S., \& Leite, M. A. D A. (2016). Agricultura digital. RECoDAF - Revista Eletrônica Competências Digitais Para Agricultura Familiar, 2(1), 72-88. Retrieved from http://codaf.tupa. unesp.br:8082/index.php/recodaf/article/view/18/42.

Ozdogan, B., Gacar, A., \& Aktas, H. (2017). Digital agriculture practices in the context of agriculture 4.0. Journal of Economics, Finance and Accounting (JEFA), 4(2), 184-191. http://doi.org/10.17261/ Pressacademia.2017.448

Piedade, M. A. (1977). Introdução à teoria da classificação, Rio de Janeiro: Interciência. 
Pipino, L. L., Yang, W. L., \& Wang, R. Y. (2002). Data quality assessment. Communications of the ACM, 45(4), 211-218. https://doi.org/10.1145/505248.506010

Pittaway, L., \& Cope, J. (2007). Entrepreneurship education: A systematic review of the evidence. International Small Business Journal: Researching Entrepreneurship, 25(5), 479-510. https://doi. org/10.1177/0266242607080656

Pozzebon, M., Freitas, H. M. R., \& Petrini, M. (1999). A definição de categorias Para o estudo de comportamentos proativos na recuperação de informações. Revista de Administração Contemporânea, 3(2), 97-118. https://doi.org/10.1590/S1415-65551999000200006

Ranganathan, S. R. (1967). Prolegomena to library classification, 3. ed., London: Asia Publishing House.

Ries, E. (2012). A startup enxuta: Como os empreendedores atuais utilizam a inovação contínua Para criar empresas extremamente bem-sucedidas, São Paulo: Lua de Papel.

Sabella, A., Farraj, W., Burbar, M., \& Qaimary, D. (2014). Entrepreneurship and economic growth in West Bank. Journal of Developmental Entrepreneurship, 19(1), 1-15. https://doi.org/10.1142/ S1084946714500034

Santos, B. P., Silva, L. A., Celes, C. S., Borges, J. B., Peres, B. S., Vieira, M. M., \& Loureiro, A. A. (2016). Internet das Coisas: da Teoria à Prática. Livro Texto Minicursos - SBRC 2016.

Santos, N. S., Ferreira, L. S., Barros, E. F. M., \& Prates, R. O. (2013). Uma análise comparativa dos métodos de avaliação de sistemas colaborativos fundamentados na engenharia semiótica. IHC "13 Proceedings of the 12th Brazilian Symposium on Human Factors in Computing Systems, 218-227. Retrieved from https://dl.acm.org/citation.cfm?id=2577146.

Schneck, S., \& May-Strobl, E. (2015). The economic contribution of start-up firms in Germany. Advances in Entrepreneurship, Firm Emergence and Growth, 17, 231-263. https://doi.org/ 10.1108/s1074-754020150000017014

Simon, H. A. (1997). Administrative behavior, 4 ed., New York, NY: The Free Press.

Spiteri, L. A. (1998). Simplified model for facet analysis: Ranganathan 101. Canadian Journal of Information and Library Science, 23, 1-30. Retrieved from http:/iainstitute.org/en/learn/ research/a_simplified_model_for_facet_analysis.php.

Torres, P., \& Alves, C. (2017). Cloud computing: As oportunidades estão nas nuvens, São Paulo: Logicalis.

Tristão, A. M. D., Fachin, G. R. B., \& Alarcon, O. E. (2004). Sistema de classificação facetada e tesauros: Instrumentos Para organização do conhecimento. Ciência da Informação, 33(2), 161-171. https:// doi.org/10.1590/S0100-19652004000200017.

\section{Corresponding author}

Paulo Henrique Bertucci Ramos can be contacted at: paulo.bertucci.ramos@gmail.com

Associate editor: Fabio Emanuel Farago

For instructions on how to order reprints of this article, please visit our website:

www.emeraldgrouppublishing.com/licensing/reprints.htm

Or contact us for further details: permissions@emeraldinsight.com 